\title{
HIGHLY SENSITIVE PERSON DAN DAMPAKNYA TERHADAP KESEHATAN MENTAL
}

\author{
Jovanka Ris Natalia*, Joshualdi Bernathsius \\ Program Studi Pendidikan Dokter, Fakultas Kedokteran Universitas Lampung \\ *nataliajovanka123@gmail.com
}

\begin{abstract}
ABSTRAK
Highly Sensitive Person atau HSP adalah sifat yang diasosiasikan dengan sensitivitas dan responsitivitas yang lebih tinggi terhadap stimulus dari internal maupun eksternal, lingkungan maupun sosial. Sifat ini dimiliki oleh $20 \%$ populasi manusia dan diturunkan secara gentik. Faktor yang berperan dalam terjadinya HSP diketahui adalah genetik dan lingkungan. Aktivitas otak pada HSP lebih tinggi daripada non-HSP hal ini akan menyebabkan overstimulasi pada otak sehingga pada HSP membutuhkan periode istirahat, dan overstimulasi ini seringkali diikuti oleh ketidakmampuan mengontrol emosi sehingga menyebabkan HSP lebih mudah mengalami gangguan kesehatan mental diantaranya adalah depresi, ansietas, dan stress. Tujuan dari artikel literature review ini adalah untuk mengenal tentang HSP, apa perbedaan HSP dengan non-HSP, bagaimana cara mengetahui individu dengan HSP, dan pengaruh HSP terhadap kesehatan mental. Metode yang digunakan dalam artikel ini adalah penelusuran artikel melalui database NCBI dan Google Scholar, lalu artikel dipilih dengan meninjau judul dan abstrak artikel. Tahun penerbitan sumber pustaka adalah dari tahun 2011 sampai 2019. Hasil dari berbagai artikel yang dicantumkan dalam artikel ini untuk menunjukkan adanya hubungan antara HSP dengan gangguan kesehatan mental seperti depresi, ansietas, dan stres.
\end{abstract}

Kata kunci : highly sensitive person, depresi, ansietas, stres

\section{HIGHLY SENSITIVE PERSON AND ITS EFFECT ON MENTAL HEALTH}

\begin{abstract}
Highly Sensitive Person or HSP is a trait associated with higher sensitivity and responsiveness to internal and external stimuli, environmental and social. This trait found in $20 \%$ of human population and genetically inherited. Factors that play a role in the occurrence of HSP are known to be genetic and environmental. Brain activity in HSP is higher than non-HSP, this will cause overstimulation of the brain so the HSP requires resting period, and this overstimulation often followed by inability to control emotion that cause HSP more vulnerable to mental health problem such as depression, anxiety, and stress. The purpose of this literature review article is to get to know about HSP, the difference between HSP and non-HSP, how to know the individuals with HSP, and HSPs effects on mental health. The method used in this article uses a review of articles from NCBI and Google Scholar databases, then the article are selected by reviewing the article titles and abstracts. The year of publication of these articles are from 2011 to 2019. The results of various articles included in this article are to show the correlations between HSP and mental health disorders such as depression, anxiety, and stress.
\end{abstract}

Keywords : highly sensitive person, depression, anxiety, stress

\section{PENDAHULUAN}

Highly Sensitive Person (HSP) atau bisa juga disebut Sensory Processing Sensitivity (SPS) adalah sifat kepribadian yang merujuk pada sensitivitas individu terhadap stimulus internal atau eksternal termasuk isyarat emosi dan sosial dengan ambang batas rendah tapi lebih mudah terpengaruh oleh stimulus tersebut dibandingkan individu lain (Grimen \& Diseth, 2016; Yano, Kase, \& Oishi, 2019). Sifat ini ditemukan pada lebih dari 100 spesies dan dimiliki oleh $20 \%$ populasi manusia (Acevedo et al., 2014).

Hal ini dapat terjadi karena terdapat perbedaan biologis pada sistem saraf pusat. Pada umumnya, informasi yang diterima oleh otak akan diproses melalui filter yang memberikan wawasan dan kesadaran terhadap lingkungan, pada HSP filter ini lebih banyak sehingga meningkatkan wawasan dan kesadaran, tetapi membutuhkan lebih banyak waktu dan energi 
untuk memproses informasi dan mengambil keputusan (O'Rourke \& Walsh, 2012). Perbedaan pada sistem saraf pusat ini disebabkan oleh konsentrasi neurotransmitter di otak (Rizzo-sierra, 2012).

Memiliki pikiran yang sangat aktif membuat HSP lebih responsif terutama setelah paparan cahaya yang terang, lingkungan yang ramai, suara yang kencang, atau bau yang menyengat. Di sisi lain, sistem saraf yang aktif meningkatkan jumlah informasi sensoris yang harus diproses otak secara simultan, membuat HSP jeli dalam melihat perbedaan sekecil apapun di lingkungan. Sensitivitas yang meningkat ini menyebabkan stimulasi sensoris berlebihan yang akan memaksimalkan kerja otak, maka dari itu HSP akan mudah merasa lelah dan kewalahan. Untuk memulihkan perasaan ini HSP cenderung pendiam dibandingkan non-HSP dan mebutuhkan waktu tidur yang lebih lama. Apabila terus terjadi stimulus yang berlebihan pada HSP, mereka akan menutup diri dan hal ini dapat menyebabkan kecemasan, depresi, kemarahan pada HSP yang seringkali penyebabnya tidak diketahui oleh orang lain (O'Rourke \& Walsh, 2012).

Beberapa penelitian menunjukkan hubungan yang signifikan antara HSP dengan gangguan kesehatan mental seperti depresi, ansietas, dan stress. Berdasarkan kondisi tersebut, maka pengenalan tentang HSP dan dampaknya terhadap kesehatan memiliki urgensi yang cukup tinggi untuk menghindari terjadinya dampak yang lebih besar pada HSP dan belum banyak jurnal maupun penelitian yang membahas tentang HSP di Indonesia. Artikel jenis literature review ini dibuat dengan tujuan untuk mengenal tentang HSP, apa perbedaan HSP dengan non-HSP, bagaimana cara mengetahui individu dengan HSP, dan pengaruh HSP terhadap kesehatan mental.

\section{METODE}

Metode yang digunakan dalam penulisan artikel ini adalah literature review. Sumber pustaka yang digunakan dalam artikel ini melibatkan 17 pustaka baik yang berasal dari buku, jurnal nasional atau internasional maupun website. Penelusuran sumber pustaka dalam artikel ini melalui database NCBI dan Google Scholar dengan kata kunci highly sensitive person, depression, anxiety, stress, sensory processing sensitivity, mental health.
Pemilihan artikel sumber pustaka dilakukan dengan melakukan peninjauan pada judul dan abstrak yaitu yang membahas tentang HSP/SPS dan yang berhubungan dengan gangguan kesehatan mental seperti depresi, ansietas, maupun stress dan sebagainya. Tahun penerbitan sumber pustaka yang digunakan dalam penulisan artikel ini adalah dari tahun 2011 sampai tahun 2019.

\section{HASIL}

Hasil penelitian Rothenbücher (2017), HSP (yang diukur dengan menggunakan HSPS) memiliki korelasi positif sedang sampai tinggi yang signifikan terhadap distress $(\mathrm{p}<0.001)$, depresi $(\mathrm{p}=0.014)$, ansietas $(\mathrm{p}=0.004)$, dan somatisasi $\quad(\mathrm{p}<0.001) \quad$ yang diukur menggunakan The Four-Dimensional Symptom Questionnaire (4DSQ).

Hasil penelitian Jonsson et al. (2014) menilai hubungan derajat HSP (diukur dengan HSPS) dengan ansietas dan depresi, optimisme, absorbsi, dan pengalaman mistis. Hasil penelitian menunjukkan hubungan yang signifikan pada derajat HSP yang rendah dengan variabel ansietas dan depresi $(\mathrm{F}(1,54)$ $\left.=9.95, \mathrm{p}<.01, \eta^{2}=.15\right) ;$ absorbsi $\mathrm{F}(1,54)=$ $10.80, \mathrm{p}<.01, \eta^{2}=.16$; dan pengalaman mistis $\mathrm{F}(1,54)=7.99, \mathrm{p}<.01, \eta^{2}=.13$, sedangkan untuk derajat HSP yang tinggi memiliki skor yang lebih tinggi pada semua variabel dibandingkan dengan derajat yang rendah (ansietas dan depresi : $\mathrm{M}=6.14, \mathrm{SD}=$ 2.96; absorbsi : $\mathrm{M}=52.75, \mathrm{SD}=27.92$; pengalaman mistis : $\mathrm{M}=105.06, \mathrm{SD}=29.13$ ). Hasil signifikansi ini menunjukkan efek medium dan tidak efek signifikan yang lain.

Penelitian Brindle et al. (2015) pada 157 partisipan usia 18-60 tahun, melihat hubungan antara SPS (diukur dengan HSPS) dengan gejala emosi negatif ansietas, depresi dan stress (diukur dengan The Depression, Anxiety, and Stress Scale (DASS)), kesulitan dalam mengontrol emosi (diukur dengan The Difficulties in Emotion Regulation Scale (DERS)) dan juga toleransi terhadap tekanan psikologi (diukur dengan The Distress Tolerance Scale (DTS)). Hasil penelitian menunjukkan bahwa HSPS memiliki hubungan yang siginifikan dengan subskala depresi DASS-21 $(\mathrm{B}=.0164, \mathrm{t}=2.71, \mathrm{p}<0.05)$ , dengan subskala ansietas $(\mathrm{B}=.0239, \mathrm{t}=4.44$, $\mathrm{p}<.001)$, dan sengan subskala stress $(\mathrm{B}=$ $.1873, \mathrm{t}=5.36, \mathrm{p}<.001)$. Penelitian Dal (2015) menunjukkan korelasi signifikan yang 
positif antara respon HSPS dengan respon Illness Atitudes Scale (IAS; r=0.43, $\mathrm{p}=0.00$ ), respon subskala Health Anxiety ( $\mathrm{r}=0.34$, $\mathrm{p}=0.00)$, dan respon subskala Illness Behavior $(\mathrm{r}=0.36, \mathrm{p}=0.00)$. Setelah dianalisis lebih lanjut respon subskala Ease of Excitation (EOE) pada HSPS berkorelasi positif dengan respon Illness Atitudes Scale (IAS; r=0.42, $\mathrm{p}=0.00$ ), respon subskala Health Anxiety $(\mathrm{r}=0.35, \mathrm{p}=0.00)$, dan respon subskala Illness Behavior $(\mathrm{r}=0.38$, p=0.00) dan subskala Low Threshold (LST) pada HSPS berkorelasi positif dengan respon Illness Atitudes Scale (IAS; $\mathrm{r}=0.42, \mathrm{p}=0.00$ ), respon subskala Health Anxiety ( $\mathrm{r}=0.36$, $\mathrm{p}=0.00)$, dan respon subskala Illness Behavior $(\mathrm{r}=0.33, \mathrm{p}=0.00)$. dalam penelitian ini, menunjukkan tidak adanya korelasi antara subskala Aesthetic Sensitivity (AE) pada HSPS dengan IAS maupun subskala-subskalanya.

\section{PEMBAHASAN}

Highly Sensitive Person memiliki tingkat kesadaran dan sensitivitas yang lebih tinggi dari rata-rata tehadap: 5 sistem indra (penglihatan, penciuman, pengecapan, pendengaran dan sentuhan); obat-obatan, kafein, alkohol dan sebagainya; emosi, baik diri sendiri maupun orang lain; perubahan kecil pada lingkungan; intuisi atau informasi ekstrasensori. Hal ini bukan berarti HSP dapat merasakan sesuatu lebih akut, hanya saja otak HSP mempersempit informasi menjadi lebih detail (O'Rourke \& Walsh, 2012). Individu HSP segera mempersepsikan dan mengalami emosi orang-orang di sekitarnya sehingga cenderung menghindari emosi dan situasi negatif. Proses kognitif internal seperti pikiran, fantasi atau ide-ide lebih memengaruhi sistem saraf HSP dibandingkan dengan non-HSP.

Situasi tertentu seperti berbicara dengan orang asing, rasa lapar, khawatir, cemas, kurang tidur, dan terutama amarah (baik dari luar maupun dari dalam diri) lebih menstimulasi respon sistem saraf pada orang HSP dibandingkan non-HSP (Rizzo-sierra, 2012).

Etiologi dari HSP sendiri adalah genetik dan lingkungan. Sifat HSP dapat diturunkan dan dapat dilihat sejak masih bayi, yaitu ditandai dengan bayi yang sangat reaktif (mudah menangis) dan akan bermanifestasi HSP pada masa remaja (Greven et al., 2018). Terdapat dua penelitian genetik molekular yang mempelajari tentang gen yang berperan terhadap HSP. Studi pertama menunjukkan adanya hubungan serotonin transporter-linked polymorphic region (5-HTTLPR) dan $s / s$ homozygosity dengan HSP atau SPS (Licht et al., 2011).

Studi genetik molekular yang kedua menilai adanya hubungan HSP dengan gen-gen yang berada pada sistem dopaminergik (Chen et al., 2011). Hal penting lainnya yang bekaitan dengan HSP adalah interaksi dengan lingkungan. Pengalaman masa kanak-kanak yang tidak menyenangkan berinteraksi dengan HSP menyebabkan afek negatif (depresi, ansietas, pemalu) di masa dewasa dibandingkan dengan anak-anak yang tidak memiliki pengalaman tidak menyenangkan (Jagiellowicz et al., 2016). Menurut Chen et al. (2011), peneliti menemukan lingkungan keluarga dan pengalaman hidup yang tidak menyenangkan meningkatkan level sensitivitas pada HSP. Chen et al. juga menghipotesiskan genetik dan lingkungan memengaruhi variasi kepribadian individu. Hasil penelitiannya menunjukkan kepribadian seseorang tergantung dengan reaksi dopamine pada sistem saraf dan sistem dopamine secara genetik berkaitan dengan kepribadian dan stress dan dapat disimpulkan bahwa gen dopamin inilah yang berkontribusi pada kepribadian HSP yang tidak dapat diprediksi.

Otak HSP diperkirakan memiliki pola konektivitas yang lebih kompleks yang menyebabkan peningkatan input informasi sensoris dan pemrosesan sensoris yang lebih dalam. Pola konektivitas yang lebih kompleks ini dimediasi oleh perbedaan konsentrasi neurotransmitter otak (asetilkolin, norepinefrin, dopamin, dan serotonin) pada HSP dibandingkan dengan non-HSP. Neurotransmitter ini memodulasi gairah pada HSP sehingga meningkatkan pemrosesan informasi dengan menghubungkan area-area relevan pada otak secara kompleks dan holistik dibandingkan non-HSP (Rizzo-sierra, 2012). Hal ini dibuktikan dengan hasil pemeriksaan functional MRI (fMRI) pada HSP lebih aktif di regio otak yang melibatkan kewaspadaan, atensi, dan pengambilan keputusan (regio cingulata dan premotor area) (Acevedo et al., 2014).

Highly Sensitive Person mudah untuk memiliki masalah kesehatan dibandingkan non-HSP, tetapi sifat sensitif ini juga memeiliki aspek positif seperti lebih teliti dan lebih baik dalam menghindari kesalahan, dan selaras anatara pikiran dengan perasaannya (Aron, 2010). 
Cooper (2015) menjelaskan peningkatan sensitivitas pada HSP berkontribusi terhadap kesulitan dalam meregulasi dan mengontrol emosi. Cooper mengumpamakan HSP seperti termometer yang mudah untuk mencapai titik didih dan akibat dari kesulitan dalam mengontrol emosi, HSP sering dikaitkan dengan stigma gila, neurotik, bipolar, dan karakteristik gangguan kepribadian. Cooper juga menyatakan HSP merasakan keinginan untuk menarik diri dari pertemuan besar karena tidak mampu mennghindari perasaan cemas.

Menurut Meindl (2019), ada lima area overstimulasi yang menyebabkan stress pada HSP: (1) overstimulasi lingkungan kronik. Overstimulasi adalah hal yang tidak menyenangkan bagi semua orang. Seseorang tidak dapat meninggalkan lingkungan yang intens dan menstimulasi secara berlebihan. Sebagai contoh, seorang ibu dengan HSP tidak dapat mengabaikan anaknya karena pelilaku sulit diatur. Meindl menilai perasaan ini akan meningkatkan risiko perasaan tak berdaya, mati rasa, dan depresi; (2) stimulasi internal tubuh. Kewaspadaan berlebihan pada HSP meningkatkan rasa tidak berdaya seseorang terhadap ansietas dan depresi; (3) kehidupan batin yang kaya dan menstimulasi. HSP tidak hanya memiliki kognisi yang detail tetapi juga intuisi akurat untuk mengantisipasi bahaya dan menghindari kemungkinan masalah. Kemampuan inilah yang berkontribusi dalam membuat HSP rentan depresi dan cemas; (4) overstimulasi interpersonal. Meindl menemukan bahawa HSP memiliki kemampuan untuk merasakan emosi sdara dan tidak sadar orang lain. Hal ini mebuat HSP cenderung terbawa oleh emosi orang disekitarnya, misalnya seseorang mengalami depresi akan sulit bagi HSP untuk tidak merasa depresi; (5) respon depresif terkait bahan kimia. Salah satu ciri HSP adalah pikiran selaras dengan fisik, sehingga kontaminasi lingkungan atau obat dengan jumlah sedikit dapat memengaruhi HSP. Contohnya, kontrasepsi oral dapat memengaruhi mood HSP, obat hipertensi dan kolesterol dapat menyebabkan munculnya gejala depresi pada HSP.

Highly Sensitive Person dapat dinilai secara kuantitatif dengan menggunakan Highly Sensitive Person scale (HSPS) yang didesain untuk menilai perbedaan tempramen terkait sensitivitas terhadap stimulus fisik, emosi, dan sosial. Skala beroperasi dengan konstruksi SPS yang merefleksikan tendensi individu dalam memproses data sensoris dari lingkungan. Kuesioner HSPS terdiri dari 27 pertaanyaan dengan tiga subskala yaitu Ease of Excitation (EOE) yang menilai kewalahan secara mental terhadap tuntutan internal maupun eksternal, Aesthetic Sensitivity (AES) yang menilai tangkapan individu tentang apresiasi dan kewaspadaan terhadap suatu keindahan, dan Low Sensory Threshold (LST) terkait dengan gairah sensoris yang tidak menyenangkan terhadap stimulus eksternal. Dalam kuesioner ini terdapat 12 pertanyaan yang menilai subskala EOE, 6 pertanyaan yang menilai subskala LST, dan 5 pertanyaan yang menilai subskala AES. Kuesioner ini diisi dalam waktu 5 menit dengan skoring menggunakan 7 poin skala likert (Gearhart, 2018).

\section{SIMPULAN}

Highly Sensitive Person (HSP) merupakan sifat individu dimana sensitivitas sensoris tubuh terhadap stimulus internal maupun eksternal meningkat. Hal ini menyebabkan HSP bisa lebih teliti dan perhatian terhadap perubahan sekecil apapun di lingkungannya. Sifat ini diturunkan secara genetik dan dipengaruhi juga oleh lingkungan. Sifat ini diketahui karena peran neurotransmitter otak yaitu sistem dopamin pada sistem saraf HSP lebih tinggi konsentrasinya dibandingkan dengan non-HSP yang membuat otak jauh lebih aktif. Hal ini dapat dilihat dari perbedaan gambaran hasil fMRI pada HSP dan non-HSP dimana gambaran otak HSP lebih aktif di regio otak yang melibatkan kewaspadaan, atensi, dan pengambilan keputusan (regio cingulata dan premotor area). Otak yang terlalu aktif menyebabkan overstimulasi, yang apabila diikuti dengan ketidakmampuan HSP untuk mengontrol emosi dapat menyebabkan gangguan kesehatan mental seperti depresi, ansietas, dan stress. Sifat HSP pada individu dapat diukur secara kuantittif menggunakan kuesioner Highly Sensitive Person scale (HSPS) yang berisi 27 pertanyaan dengan tiga subskala yaitu Ease of Excitation (EOE), Aesthetic Sensitivity (AES), dan Low Sensory Threshold (LST).

\section{DAFTAR PUSTAKA}

Acevedo, B. P., Aron, E. N., Aron, A., Sangster, M., Collins, N., \& Brown, L. L. (2014). The Highly Sensitive Brain: an fMRI Study of Sensory Processing 
Sensitivity and Response to Others Emotions. Brain and Behavior: 1-15.

Aron, E. N. (2010). Psychotherapy and The Highly Sensitive Person: Improving Outcomes for That Minority of People Who Are The Majority of Clients. New York: Routledge, Taylor \& Francis Group.

Brindle, K., Moulding, R., Bakker, K., \& Nedeljkovic, M. (2015). Is the relationship between sensory-processing sensitivity and negative affect mediated by emotional regulation?. Australian Journal of Psychology: 1-8.

Chen, C., Chen, C., Moyzis, R., Stern, H., He, Q., Li, H., ... Dong, Q. (2011). Contributions of Dopamine-Related Genes and Environmental Factors to Highly Sensitive Personality: A MultiStep Neuronal System-Level Approach. PLoS ONE, 6(7): 1-9.

Cooper, T. (2015). Thrive: The Highly Sensitive Person and Career. Ozark: Invictus Publishing, LLC.

Dal, S. (2015). Relationship between sensory processing sensitivity and hypochondriacal features and the moderating role of somatic symptoms. Biomedical and Health Sciences Research 6: 351-359.

Gearhart, C. C. (2018). Highly Sensitive Person Scale (HSPS). John Wiley \& Sons, Inc : 299-305.

Greven, C. U., Lionetti, F., Booth, C., Aron, E. N., Fox, E., Schendan, H. E., ... Homberg, J. (2018). Sensory Processing Sensitivity in the Context of Environmental Sensitivity: A Critical Review and Development of Research Agenda. Preprint: 1-74.

Grimen, H. L., \& Diseth, A. (2016). Sensory Processing Sensitivity: Factors of the Highly Sensitive Person Scale and Their relationships to Personality and
Subjective Health Complaints. Comprehensive Psychology 5: 1-10.

Jagiellowicz, J., Aron, A., Aron, E. N., Brook, S., Yu, K., Varfolomeyeva, A., \& Brook, S. (2016). Relationship Between The Temperaments Trait of Sensory Processing Sensitivity and Emotional. Social Behavior and Personality, 44(2), 185-199.

Jonsson, K., Grim, K., \& Kjellgren, A. (2014). Do Highly Sensitive Persons Experience More Nonordinary States of Consciousness During Sensory Isolation?. Social Behavior and Personality, 42(9): 1495-1506.

Licht, C. L., Mortensen, E. L., \& Knudsen, G. M. (2011). Association between Sensory Processing Sensitivity and the 5HTTLPR Short / Short Genotype. Cimbi, 2011.

Meindl, S. (2019). Highly Sensitive People and Depression: Overstimulation May Lead to Depression. Dalam http://highlysensitive.org/highlysensitive-people-and-depressionoverstimulation-may-lead-to-depression/. Diakses 14 November 2019.

O'Rourke, C., \& Walsh, E. (2012). The Highly Sensitive Person: Introductory Guide. Plum Turtle Coaching: 1-11.

Rizzo-sierra, C. V. (2012). The Human Sensory Processing Sensitivity: Biological Implications for Introversion, Submission and Creativity. Yoga University.

Rothenbucher, F. U. (2017). Sensory Processing Sensitivity and Attentional Bias - A Pilot Study. Vrije Universiteit Brussel.

Yano, K., Kase, T., \& Oishi, K. (2019). The effects of sensory-processing sensitivity and sense of coherence on depressive symptoms in university students. Health Psychology Open: 1-5. 
Jurnal Keperawatan Jiwa Volume 7 No 3 Hal 317 - 322, November 2019

FIKKes Universitas Muhammadiyah Semarang bekerjasama dengan PPNI Jawa Tengah 